\title{
BATTLE ON THE LOMBA, 1987 THE DAY A SOUTH AFRICAN ARMOURED BATTALION SHATTRED ANGOLA'S LAST MECHANISED OFFENSIVE: A CREW COMMANDER'S ACCOUNT
}

\section{David Mannall}

Solihull: Helion \& Company

2014

Paperback, 246 pages

ISBN 9781909982024

Order directly from the author at www.davidmannall.com; Helion $£ 17.96$, Bush War Books R375

Writing about the Namibian Border War and South African involvement in the Angolan Civil War is difficult. Many South Africans have been conscripted or willingly served in the military at the time and find it difficult to distance themselves from their own experiences and their personal involvement in many of the operations that were conducted by the South African military. The issue is also clouded by the current South African government's association with what happened on the other side of the hill ${ }^{1}$ and, more specifically, their support for the winning narrative of the Cuban-Angolan forces. Many previous South African Defence Force (SADF) soldiers are also facing the wounds of post-traumatic stress because of their exposure to the battlefield experiences of the war. It is very often difficult to navigate between perceptions and reality and to find the truth in the debate about who won the so-called Battle for Cuito Cuanavale.

A more recent trend in the writing about South African involvement in both the Namibian war for independence and the Angolan Civil War is the so-called histories from below: individual servicemen who write about their individual experiences. The quality of these writings varies significantly from quite good to appallingly bad. The Battle of the Lomba, 1987: A crew commander's account by David Mannall stands out as one of the better publications in this particular Border

Scientia Militaria, South African Journal of Military Studies, Vol 43, No. 2, 2015, pp. 204-207. doi : $10.5787 / 43-2-1132$
War genre. Mannall, who also struggled with post-traumatic stress because of his experiences in Angola in the latter part of 1987 , is quite honest that he wrote the book in 
an effort to deal with the demons from the past and that "... exposing battle scars doesn't come easily". ${ }^{2}$

As a student of war for more than twenty years, one sometimes think that you have more or less seen it all - albeit through the eyes of others. And then you read a book like The Battle of the Lomba, 1987: A crew commander's accountonly to realise what a fine art it is to pen down the horrors of war and the experiences of soldiers in battle. Reading Mannall's book, and specifically Chapter 16 on The Battle of the Lomba, is intense, emotional and moving. 'Respect' is the word that comes up when reading what the men of 61 Mechanised Battalion Group did in the latter part of 1987 as part of SADF's Operation Modular in Angola in general and on 3 October 1987 in particular. As a crew commander of Charlie Squadron of 61 Mechanised Battalion Group, Mannall was in the leading group in the attack by 61 Mechanised Battalion Group on Fapla's ${ }^{3} 47$ Brigade on 3 October 1987.

One of the most outstanding features of the book is the honesty with which the author is telling his story. He notes that he is "... no historian and had no reason to believe [his] account of the war in Angola and exploits with Charlie Squadron, 61 Mechanised Battalion [Group] would ever be told." 4 The author highlights the fact that he struggled "... to communicate [his] experiences and, quite truthfully, even to find an audience who took [his] story at face value." $\mathrm{He}$, thus, notes that he realises "... how difficult it is for the listener to comprehend a story about something remote to him but yet so vivid, real, and painful for the storyteller." 6

The scope of the book, though, is much wider than the events at the latter part of 1987 and the Battle of the Lomba on 3 October 1987. The author takes the reader on the journey that "... delivered me and my comrades to that historic moment, and as much as I can remember of the dark weeks that followed when we chased a retreating enemy; when youthful exuberance was replaced by something different altogether and somewhat at odds with the views of mainstream society."7 In doing that, the author is quite honest that he relies on his own memory and, as such, the book focuses mostly on major events and actions augmented by anecdotes from a small number of his comrades in arms. In essence, though, the book tells the story as the author remembers it. ${ }^{8}$ In doing that, the author is aware that "... there are doubtless many amusing moments I've forgotten - and my recollection of many physically demanding or emotionally painful days have long-since paled into insignificance as the memory of the horror of war starved them of 'cranial airtime'.,"9 
It is possible to divide the discussion into three parts. The first part recounts the story of Mannall's experiences as a typical conscript undergoing basic and junior leadership training in the South African Army in the 1980s - in his case, at the School of Armour in Bloemfontein. His experiences as an English-speaking trainee in a predominantly Afrikaans-speaking Army make for interesting reading. Maybe it is this specific factor that is responsible for the distance between the writer and his subject that allowed him to write with greater objectivity than is normally the case in this particular genre of military writing in South Africa.

The second part narrates his story as a crew commander with Charlie Squadron, 61 Mechanised Battalion Group stationed at Omuthiya in northern Namibia. It was as part of this unit that he participated in the fighting that ensued inside Angola at the Lomba River in the later part of 1987. The chapter dealing with his experiences as part of the Battle of the Lomba on 3 October 1987 succeeds in giving the reader a real personal experience of what it was like to fight a highly mobile battle in the dense bushes of Angola in the absence of air superiority and against an enemy whose fighting vehicles outgunned their own. Mannall's description of the battle is authentic, it's hair-raising, and it's frank. "It just so happends," Mannall writes, "that I am very well placed to share my front-row-seat view of those dramatic hours." ${ }^{10}$ He writes with compassion about the death of his comrades. Although the author is writing about his own role in the battle, the reader is left in awe about the achievements of a small group of soldiers against overwhelming odds.

The last part of the book covers the aftermath of the Battle of the Lomba and the author's surreal experience of leaving the army and returning to civilian life. Like so many of the books in this genre, ${ }^{11}$ The Battle of the Lomba, 1987 tends to leave the reader with a feeling of hollowness and the question of whether the South African military effort was really worth it. "Landing in Durban airport was a lowkey event," Mannall writes, "no state-sponsored fanfare, no brass band, but being reunited with my family was the highlight. They asked me for information on the war. 'We were in some big battles Dad,' was about all I could say". ${ }^{12}$

Who should read this book? Of course, the veterans of the various South African battles and campaigns in Namibia and Angola would be interested in reading the book. However, the book should also be read by the new generation of officers of the South African military. The book provides an excellent exposition of how a small group of soldiers, with slightly inferior technology, could overcome overwhelming odds because of the quality of their training and their discipline. The cohesion of a small fighting unit - rooted in training and discipline as the primary instruments to turn a band of men fighting as individuals into soldiers fighting as an 
organised unit - is probably the most important lesson of the book as a whole. The band-of-brothers principle still applies in the modern era. The need for discipline and small unit cohesion is a lesson that the South African military should take to heart.

Prof Abel Esterhuyse, Stellenbosch University

\section{Endnotes}

${ }^{1}$ With reference to Liddell Hart's account of the German generals in the aftermath of the Second World War, their views of the military events of 1939-1945 and details of their rise and fall. See Liddell Hart, BH. The other side of the hill. London: Pan Books, 1999.

${ }^{2}$ Mannall, D. Battle of the Lomba, 1987: The day a South African armoured battalion shattered Angola's last mechanised offensive. Solihull: Helion, 2014, xiii.

${ }^{3}$ Forças Armadas Populares de Libertação de Angola, Angola's official armed forces since the MPLA government came to power in 1975. Loosely translated into English it is the People's Movement for the Liberation of Angola.

${ }^{4}$ Mannall op. cit., p. xiii.

${ }^{5}$ Ibid.

${ }^{6}$ Ibid.

${ }^{7}$ Ibid., p. xvii

${ }^{8}$ Ibid.

${ }^{9}$ Ibid.

${ }^{10}$ Ibid., p. 168.

${ }^{11}$ The most outstanding books to recommend in this regard is Robert Mason's Chickenhawk (Viking-Penguin, New York, 1983) and Granger Korff's 19 with a bullet: A South African paratrooper in Angola, (30 Degrees South, Cape Town, 2009).

${ }^{12}$ Mannall op. cit., p. 240. 